\title{
Correction
}

\section{Correction: Pristane-Induced Arthritis Loci Interact with the S/c11a1 Gene to Determine Susceptibility in Mice Selected for High Inflammation}

\section{The PLOS ONE Staff}

The name of the $12^{\text {th }}$ author is incorrectly given in the author byline. The correct name is: Tommaso A. Dragani.

\section{Reference}

1. De Franco M, Peters LC, Correa MA, Galvan A, Canhamero T, et al. (2014) Pristane-Induced Arthritis Loci Interact with the Slcllal Gene to Determine Susceptibility in Mice Selected for High Inflammation. PLoS ONE 9(2): e88302. doi:10.1371/journal.pone.0088302 